\title{
EFFECT OF UNDERNUTRITION ON TESTICULAR BLOOD FLOW AND METABOLISM AND THE OUTPUT OF TESTOSTERONE IN THE RAM
}

\author{
B. P. SETCHELL, G. M. H. WAITES AND H. R. LINDNER
}

C.S.I.R.O. Division of Animal Physiology, Ian Clunies Ross Animal Research Laboratory, Prospect, N.S.W., Australia

(Received 7th Fuly 1964)

\begin{abstract}
Summary. The food intake of six rams was restricted for 3 months, resulting in a reduction of body fat to less than $12 \%$ of live weight, compared with 25 to $49 \%$ in well-fed controls. At the end of this period of undernutrition, blood flow and the uptake of oxygen and glucose in unit weight of testis, when estimated during anaesthesia, were lower than in the controls, and testis weight was reduced. The fraction of oxygen uptake that could be accounted for by the oxidation of glucose was unchanged, although the respiratory quotient was slightly higher in the underfed rams. Oxygen uptake by homogenates and mitochondria from the testes of underfed rams was lower under most conditions of incubation applied.

Testosterone output ( $\mathrm{mg} / \mathrm{ram} /$ day \pm s.E.M.) was $0.4 \pm 0.2$ in the underfed rams and $3.5 \pm 0.7$ in well-fed controls; in six other well-fed rams, sampled while conscious, testosterone output was $2 \cdot 8 \pm 0 \cdot 3$. Spermatogenic activity, as indicated by the diameter of the seminiferous tubules and the sperm content of the epididymis, and accessory gland activity, as indicated by the weight and fructose content of the seminal vesicles, were lower in the underfed rams. All these indices appeared to be related to testosterone output when the latter was less than $2.5 \mathrm{mg} / \mathrm{ram} /$ day, but tended to attain maximal values at higher rates of hormone production
\end{abstract}

\section{INTRODUCTION}

Early workers were able to demonstrate by histological examination that underfeeding brought about degenerative changes in the testes of pigeons (Grandis, 1889), rabbits and guinea-pigs (Simonowitsch, 1896). In man, undernutrition has also been reported to result in decreased libido and semen production (Miles, 1919; Rubner, 1919), while in the dog a fall in both the concentration and motility of spermatozoa in the semen has been observed (Poiarkov, 1913). Many subsequent investigations have confirmed the importance of nutrition for testicular function (see Leathem, 1959; Moustgaard, 1959; Moule, 1963). Although the mechanism by which undernutrition affects testicular function is not fully understood, there is evidence that this effect is mediated, at least in 
part, by the anterior pituitary gland (Samuels, 1950), and the condition has been referred to as 'pseudohypophysectomy' (Mulinos \& Pomerantz, 1941).

The purpose of the present study was to define the changes in blood flow and the uptake of glucose and oxygen in the testis and epididymis of the undernourished ram, and to examine the effect of undernutrition on the production of testosterone.

\section{MATERIALS AND METHODS}

\section{ANIMALS AND FEEDING REGIME}

Twelve rams aged 3 to 5 years (eight of the Merino breed and four English Leicester $\times$ Merino cross), weighing between 40 and $65 \mathrm{~kg}$, were allocated at random to two groups. In January 1963, six rams were placed in one pen and fed ad libitum on a mixture containing $12.5 \%$ crude protein, consisting of equal parts of chaffed lucerne hay and oat grain, of which they ate about $1500 \mathrm{~g}$ / sheep/day, representing approximately $6000 \mathrm{kcal} /$ day. The other six rams were kept singly and fed $500 \mathrm{~g} /$ day of a mixture of equal parts of chaffed lucerne and wheaten hay. This ration contained $10.5 \%$ crude protein of which about $80 \%$ was digestible and $2000 \mathrm{kcal}$ gross energy of which about $60 \%$ was digestible. All rams were given vitamins A and D (500,000 units of each) 8 weeks after the start of the experiment. The well-fed group gained weight for 4 to 6 weeks and then stayed reasonably constant at 57 to $83 \mathrm{~kg}$ bodyweight. The second group lost weight throughout the experiment at an overall rate of 0.6 to $1.2 \mathrm{~kg} /$ week (total weight loss 22 to $38 \%$ of initial weight), but to maintain this rate of weight loss after 11 weeks, the amount fed had to be reduced to $300 \mathrm{~g} /$ day.

\section{GOLLECTION OF BLOOD AND TISSUE}

Blood samples were collected from the jugular vein at fortnightly intervals. The plasma was analysed for protein by the method of Tombs, Souter \& Maclagan (1959) and for glucose by the method of Huggett \& Nixon (1957).

After the test ration had been reduced to $300 \mathrm{~g}$, blood flow and metabolic activity were estimated each week in one well-fed control and one underfed ram. The underfed ram in poorest body condition, judged subjectively, was used on each occasion, while the well-fed rams were used in random order. The rams were anaesthetized with intravenous pentobarbitone sodium B.P. $16 \mathrm{hr}$ after food had been removed. Polyethylene catheters $(1 \mathrm{~mm}$ i.d., $0.25 \mathrm{~mm}$ wall thickness) were inserted into a carotid artery, both internal spermatic veins, and one external jugular vein, and the ram was suspended in a sling with the legs and scrotum dependent. The temperature of the subcutaneous tissues of the scrotum was recorded with thermocouples and kept within the range 32 to $35^{\circ} \mathrm{C}$ by local radiant heating and conductive cooling as described by Setchell \& Waites (1964). An estimate of testicular blood flow was obtained from ten sets of blood samples withdrawn during 20 min through the carotid and spermatic venous catheters using tritiated water as the dilution substance (Setchell \& Waites, 1964). These blood samples were also used to determine arteriovenous (A-V) differences in plasma glucose concentration. Oxygen saturation and 
haemoglobin concentration were determined on the second, fifth and ninth sets of samples, using methods previously described (Setchell \& Waites, 1964).

Immediately after drawing the blood samples for the estimation of blood flow further samples of 40 to $60 \mathrm{ml}$ were removed, at a rate of about $6 \mathrm{ml} / \mathrm{min}$, from each spermatic vein. These were used for the determination of testosterone by the method of Lindner $(1961,1963)$.

Portions of the testis were then taken for histological and in-vitro metabolic studies, and the epididymis was dissected off for the estimation of its content of spermatozoa (Ortavant, 1952; Amann \& Almquist, 1961). The rams were kept anaesthetized for a further $5 \mathrm{hr}$. At the end of this period a blood sample was removed from the jugular vein for a tritium determination, from which total body water, and hence body fat, was estimated (Panaretto \& Till, 1963). The animal was then killed with an overdose of pentobarbitone sodium B.P. The viscera were removed and weighed. The fructose content of the seminal vesicles was estimated by the method of Lindner \& Mann (1960).

One of the well-fed rams died during the experiment, another became hyperglycaemic following a brief period of hypoxia during anaesthesia, and a third was found to have one fibrosed testis. Thus only seven testes from four well-fed rams yielded valid measurements of blood flow and metabolism for comparison with data from the six underfed rams. Blood for androgen analysis was collected from five of the underfed rams, the samples from the two testes being pooled. Samples from the testes of the well-fed rams were collected and analysed individually.

In order to examine to what extent testosterone output was affected by anaesthesia, concurrent determinations of testosterone concentration and blood flow were also carried out in six conscious well-fed rams from the same flock. Samples were drawn from both testes of each ram and pooled for analysis; two rams were sampled again $4 \mathrm{hr}$ later.

\section{IN-VITRO STUDIES}

Portions of the testis and four volumes of $0.25 \mathrm{M}$-sucrose neutralized with 0.25 M-Tris (2-amino-2-hydroxymethyl-propane-1:3-diol) (Werkheiser \& Bartley, 1957) were macerated with a MSE top drive macerator. The suspension was filtered through nylon gauze and then homogenized with an all-glass homogenizer. Portions of the homogenate were used directly; the remainder was centrifuged at $2000 \mathrm{~g}$ for $15 \mathrm{~min}$ to remove intact cells and nuclei. The supernatant was recentrifuged at $10,000 \mathrm{~g}$ for $15 \mathrm{~min}$ and thus a second precipitate separated. That precipitate, obtained from $10 \mathrm{ml}$ of homogenate and resuspended with $1 \mathrm{ml}$ sucrose solution, will be referred to as cell particles. Although no attempt was made to identify the particles sedimented, it is likely that this fraction consisted chiefly of mitochondria.

Portions of the homogenate or of the suspension of cell particles were added to Warburg flasks ( $6 \mathrm{ml}$ or $17 \mathrm{ml}$ approximately) containing one of the media described by Gallagher \& Buttery (1959) $(0.1 \mathrm{ml}$ of the tissue preparation to a total volume of $0.5 \mathrm{ml}$, or $0.4 \mathrm{ml}$ to a total volume of $2.0 \mathrm{ml}$, depending on the size of flask used). Substrates used were glucose, citrate and glutamate (each 
$10 \mathrm{~mm}$ ) in the medium described as 'standard', and acetate, $\beta$-hydroxybutyrate (each $10 \mathrm{~mm}$ ) and octanoate $(1.67 \mathrm{~mm}$ ) in the special medium described by Gallagher \& Buttery (1959) in Table 6 of their paper. All media and substrates were tested for inhibitory impurities by incubation with rat liver homogenates and mitochondria. Equilibration was for $10 \mathrm{~min}$, and incubation for $45 \mathrm{~min}$ in air at $39^{\circ} \mathrm{C}$. Nitrogen in the homogenates and particulate suspensions was determined by the method of McKenzie \& Wallace (1954), and oxygen uptakes were expressed as $\mu \mathrm{l}$ oxygen $/ \mathrm{mg}$ nitrogen/hr.

\section{HISTOLOGIGAL STUDIES}

Pieces of testis were either fixed in Helly's and stained with Sudan black to demonstrate interstitial cells (Threadgold, 1957) or fixed in Zenker's fluid and stained with periodic acid Schiff to stain the basement membrane (Montagna, 1952).

The mean diameter of the seminiferous tubules was determined according to the method of Hay, Lindner \& Mann (1961).

\section{RESULTS}

TESTIS WEIGHT AND BODY COMPOSITION

Fat constituted 25 to $28 \%$ by weight of the body of four well-fed rams and $49 \%$ of the fifth; all the underfed rams had less than $12 \%$ fat. The size of the testis, whether expressed as weight (Text-fig. 1) or as a percentage of body weight, was markedly smaller in the underfed rams. In the well-fed rams the testes were $0.38 \pm 0.025 \%$ (mean and s.E. of mean) of the body weight, whereas in the underfed rams, they were $0.27 \pm 0.018 \%$ of the body weight. A parallel reduction in epididymal weight was observed, and the weight of the epididymides of the underfed rams retained the relationship to testicular weight previously observed in adequately fed rams (Setchell \& Waites, 1964). No other organ examined constituted a lower percentage of body weight in the underfed animals than in the well-fed animals. Thus brain, lungs, thyroid and suprarenals maintained their absolute weight. Liver, heart, gut and the muscles of the thigh (semimembranosus, biceps femoris, semitendinosus and gastrocnemius) lost slightly less weight than the body as a whole, and kidney and spleen lost the same proportion of their weight as the whole animal.

Plasma protein concentration in the underfed rams declined slightly during the experiment, and by the second week there was a significant difference between the two groups. However, the mean plasma protein concentration in the underfed rams was $7 \cdot 2 \pm 0 \cdot 2 \mathrm{~g} / 100 \mathrm{ml}$ after 11 weeks of underfeeding when that of the well-fed rams was $8 \cdot 8 \pm 0 \cdot 3 \mathrm{~g} / 100 \mathrm{ml}$.

\section{TESTICULAR BLOOD FLOW}

The blood flow through unit weight of testis and epididymis was lower $(P<$ 0.05 ) in the undernourished rams, and, since testicular weight was also lower, the total blood flow through the testis and epididymis was markedly reduced. Blood flow through unit weight was related to testicular weight, particularly when this was less than $150 \mathrm{~g}$ (Text-fig. 1). 


\section{(i) In vivo GLUCOSE AND OXYGEN UPTAKE BY THE TESTIS}

The concentration of glucose in the plasma was similar in the well-fed and underfed rams (45 to $60 \mathrm{mg} / 100 \mathrm{ml}$ ) throughout the experiment and thus remained within the normal range (Reid, 1950). The uptake of glucose and of oxygen by unit weight of testis and epididymis was significantly less in the
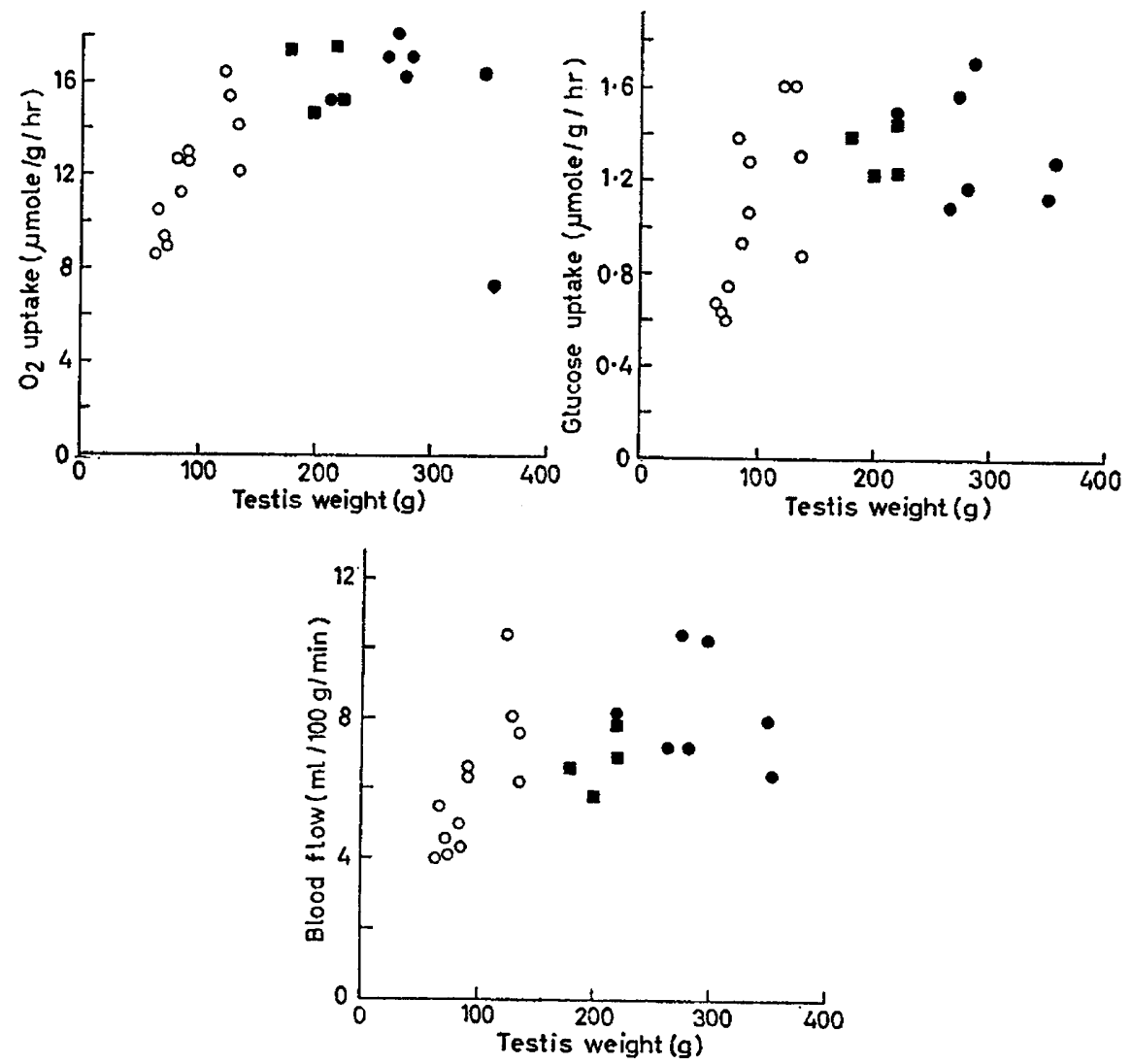

TEXT-FIG. 1. The relationship between testis weight and testicular blood flow, oxygen uptake and glucose uptake. 0 , well-fed rams; $O$, underfed rams; $\square$, well-fed anaesthetized rams from earlier experiments by Setchell \& Waites (1964).

undernourished rams. Both oxygen and glucose uptakes were correlated with testicular weight, although one estimate of oxygen uptake was unaccountably lower than the rest (Text-fig. 1). The percentage of the oxygen uptake that could be accounted for by the oxidation of glucose was similar in the underfed rams $(52 \pm 2.5 \%)$ and in the well-fed rams $(57 \pm 8 \%)$, but the respiratory quotient (R.Q.) for the testis was significantly higher in the underfed rams $(0.93 \pm$ $0 \cdot 018)$ than in the well-fed rams $(0 \cdot 86 \pm 0 \cdot 027)$.

(ii) In vitro

Values for oxygen uptake by testicular homogenates and particulate suspensions in the presence of various substrates are given in Table 1 . When no 
substrate was added, the homogenates from underfed rams used significantly less oxygen than the homogenates from well-fed rams. The oxygen uptake by homogenates from both groups was significantly increased when acetate or $\beta$-hydroxybutyrate was added. The percentage increase was similar in both groups, and consequently the oxygen uptake in the presence of acetate or $\beta$ hydroxybutyrate was lower for homogenates from underfed rams.

There was no difference in oxygen uptake between suspensions of cell particles from the two groups of rams when no substrate was added. However, in the presence of either citrate or acetate the oxygen uptake of the cell particles from well-fed rams was significantly increased, whereas no such increase was observed with particles from undernourished rams. When $\beta$-hydroxybutyrate was added

TABLE 1

OXYGEN UPTAKE $(\mu 1 / \mathrm{mg} \mathrm{N} / \mathrm{hr})$ BY PREPARATIONS FROM TESTES OF WELL-FED AND UNDERFED RAMS

(For details see text)

\begin{tabular}{|c|c|c|c|c|}
\hline & \multicolumn{2}{|c|}{ Homogenate } & \multicolumn{2}{|c|}{ Cell particles } \\
\hline & Well-fed & Underfed & Well-fed & Underfed \\
\hline $\begin{array}{l}\text { 'Standard' medium } \\
\text { No substrate } \\
\text { Glucose } \\
\text { Citrate } \\
\text { Glutamate }\end{array}$ & $\begin{array}{l}26 \pm 3^{*} \\
25 \pm 4 \\
20 \pm 3 \\
21 \pm 2\end{array}$ & $\begin{array}{l}16 \pm 2 \\
15 \pm 2 \\
16 \pm 2 \\
20 \pm 3\end{array}$ & $\begin{array}{l}25 \pm 3 \\
28 \pm 3 \\
49 \pm 5 \\
40 \pm 6\end{array}$ & $\begin{array}{l}25 \pm 4 \\
16 \pm 3 \\
25 \pm 3 \\
31 \pm 4\end{array}$ \\
\hline 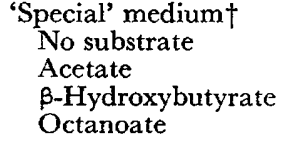 & $\begin{array}{l}56 \pm 7 \\
95 \pm 12 \\
92 \pm 10 \\
56 \pm 6\end{array}$ & $\begin{array}{l}37 \pm 4 \\
61 \pm 6 \\
73 \pm 5 \\
40 \pm 4\end{array}$ & $\begin{array}{r}41 \pm 4 \\
88 \pm 10 \\
120 \pm 8 \\
37 \pm 5\end{array}$ & $\begin{array}{l}35 \pm 4 \\
37 \pm 4 \\
55 \pm 11 \\
27 \pm 6\end{array}$ \\
\hline
\end{tabular}

* Mean \pm standard error of mean; ten observations.

t Gallagher \& Buttery (1959), Table 6.

to the medium, the oxygen uptake of cell particles from both groups was increased, but the observed increase was much larger for the preparations from well-fed rams. The oxygen uptake by cell particles in media containing acetate or $\beta$-hydroxybutyrate was related to the weight of the testis (Text-fig. 2).

\section{TESTOSTERONE OUTPUT}

The output of testosterone by the testes of the underfed rams was markedly less than that by the testes of the well-nourished rams (Text-fig. 3). The values for testosterone output in the well-fed anaesthetized rams $(3.5 \pm 0.7 \mathrm{mg} / \mathrm{ram} /$ day) were similar to those seen in the conscious rams $(2 \cdot 8 \pm 0.3 \mathrm{mg} / \mathrm{ram} /$ day $)$. In the underfed rams, the testosterone output was only $0.4 \pm 0.2 \mathrm{mg} / \mathrm{ram} /$ day.

Testosterone output was closely related to the weight of the testis and to the concentration of testosterone in the blood flowing through the internal spermatic veins. There was a less definite relationship between the output of testosterone and plasma flow through unit weight of the testis and epididymis, although this too was less in the undernourished animals (Text-fig. 3). 
The weight and fructose content of the seminal vesicles were also considerably less in the underfed rams; both measurements were related to testosterone output at the lower levels, but tended to approach maximal values when the output of testosterone was more than $100 \mathrm{\mu g} / \mathrm{hr}$ (Text-fig. 4).

Interstitial cells were clearly visible in the Sudan black stained preparations from the well-fed rams (Pl. 1, Fig. 3). The cells were deeply stained and arranged close to blood vessels; in one preparation numerous cells were observed in the tunica albuginea (Pl. 1, Figs. 1 and 2). By contrast, the interstitial cells in the

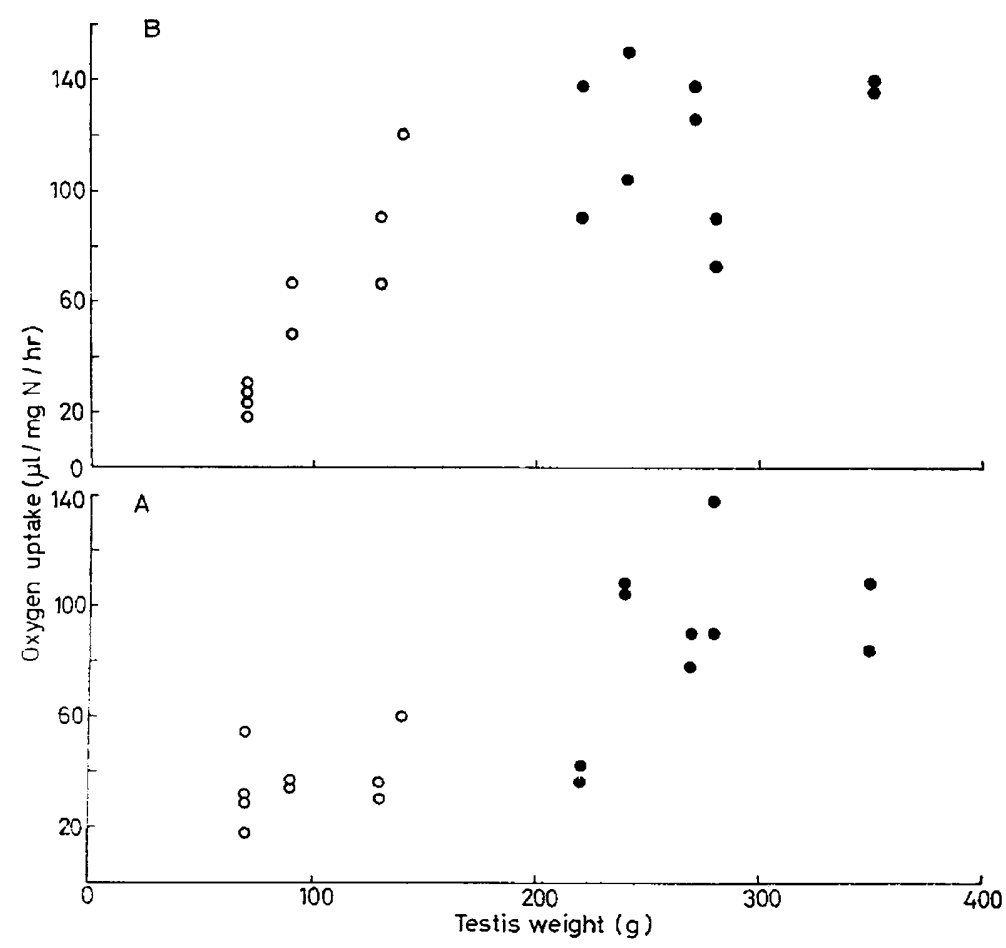

Text-Fig. 2. Oxygen uptake by particulate preparations (chiefly mitochondria) from testes of well-fed (O) and underfed (O) rams. Added substrate: A, acetate; B, $\beta$-hydroxy* butyrate.

testes of underfed rams were few and lightly stained, while deeply stained fat vacuoles were seen in the seminiferous tubules (PI. 1, Fig. 4).

SPERMATOGENESIS

The seminiferous tubules were significantly smaller in the underfed rams than in the well-nourished animals. The tubular diameters increased with the output of testosterone when secretion rates were within the limits of 5 to $100 \mu \mathrm{g} / \mathrm{hr}$ (Text-fig. 4).

The seminiferous tubules of the testes of the well-fed rams were normal and showed active spermatogenesis (Pl. 1, Fig. 1). Tubular damage of varying degrees was present in the testes of all underfed rams. In two of these most of the tubules were normal, while in adjacent tubules sloughing of cells into the lumen had 
occurred; the lumina of the latter tubules also contained multi-nucleated cells. In the remaining rams, many of the tubules showed extreme sloughing; in some places only the Sertoli cells and spermatogonia remained attached to the basement membrane, and the lumina contained cellular debris and fat droplets

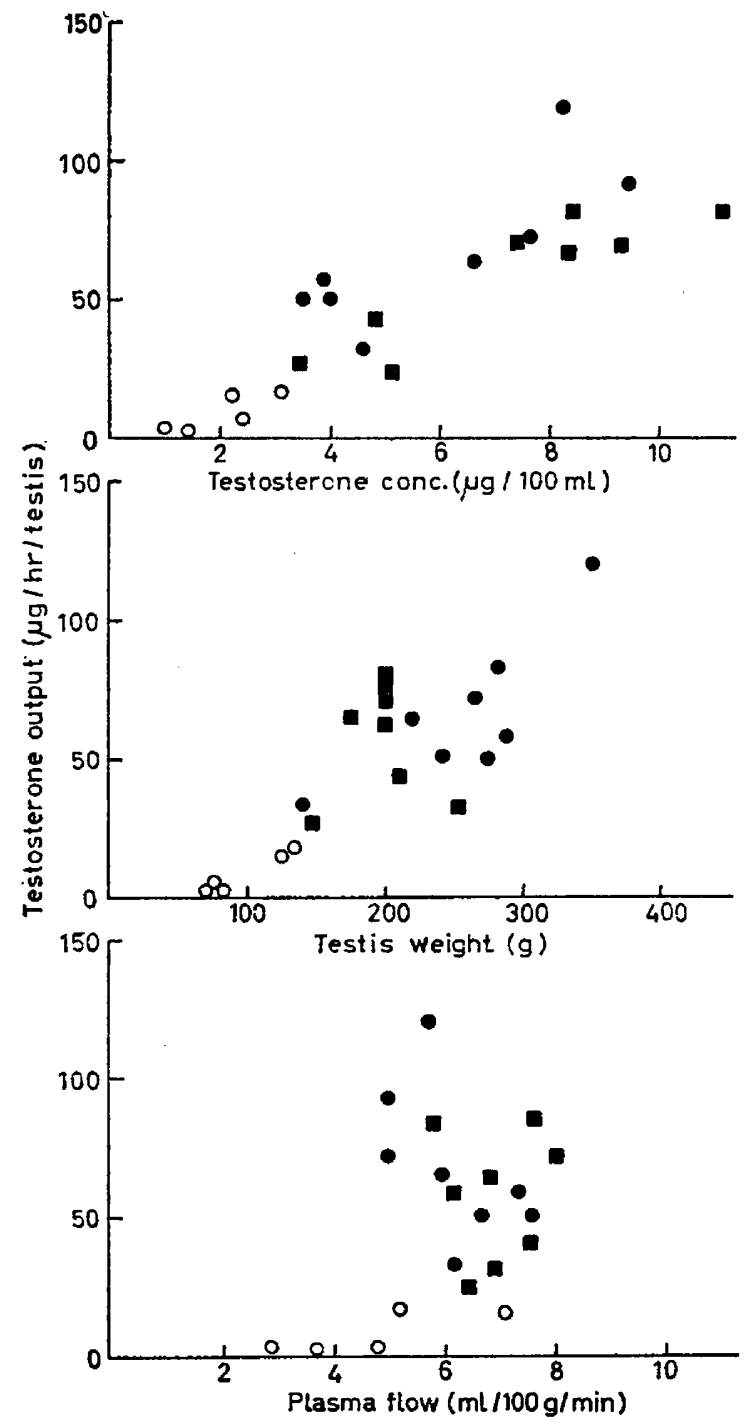

TexT-FIG. 3. The relationship between testosterone output and plasma flow in the spermatic vein, testis weight and the concentration of testosterone in the spermatic vein plasma. , $O$, well-fed and underfed anaesthetized rams; $\square$, well-fed conscious rams.

(Pl. 1, Fig. 4). However, spermatogenesis could be detected in all testes of underfed rams.

The epididymides of the underfed rams contained between 13 and $36 \times 10^{9}$ spermatozoa per epididymis compared with 49 to $109 \times 10^{9}$ spermatozoa per epididymis in the well-fed rams. 
PLATE 1

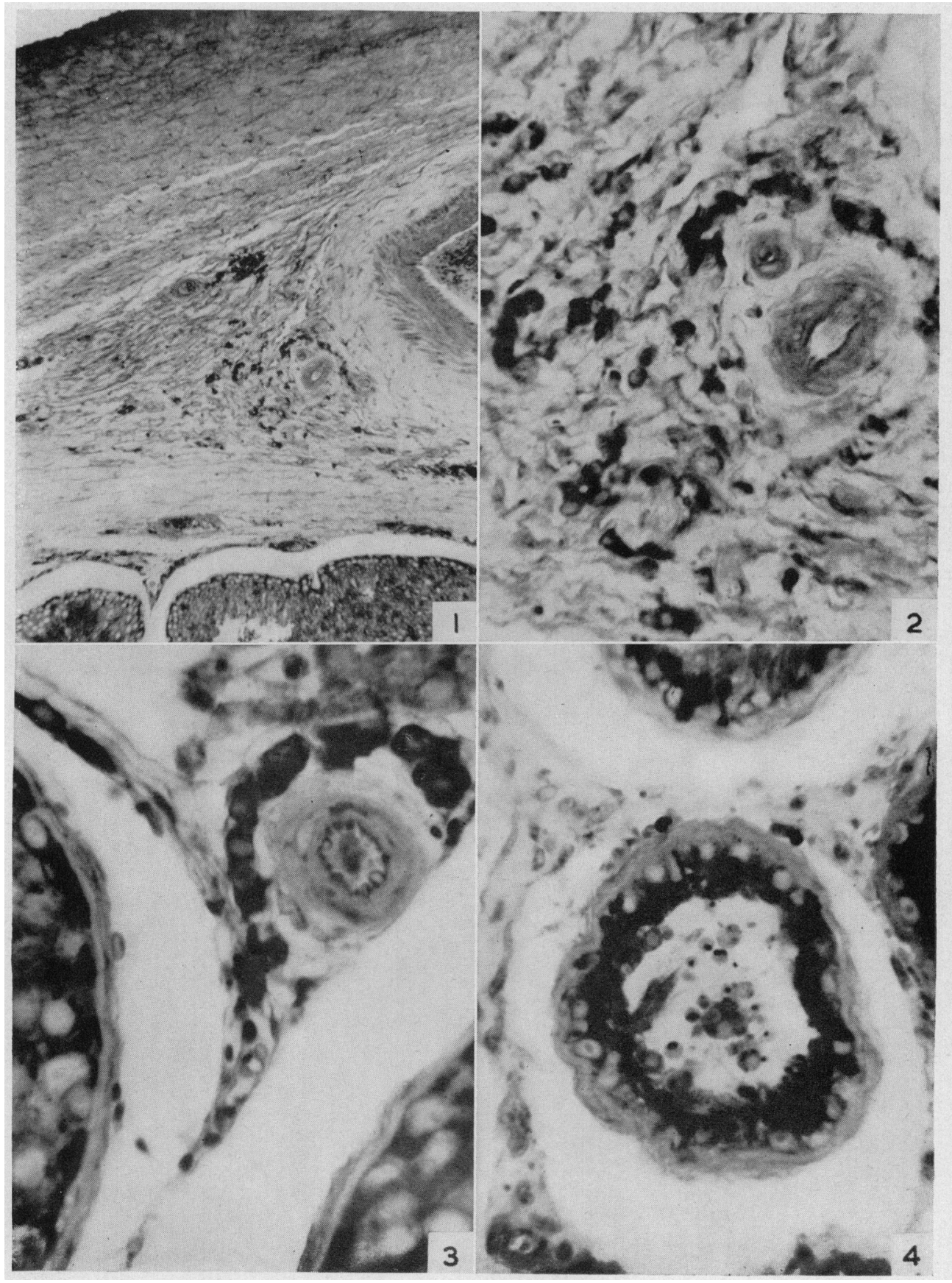

Fig. 1. Interstitial cells in the tunica albuginea of a well-fed ram. Sudan black. $\times 80$ diam.

Fig. 2. Higher magnification ( $\times 320$ diam.) of part of Fig. 1 .

Frg. 3. Dark staining interstitial cells around an arteriole in the testis of a well-fed ram. Sudan black. $\times 580$ diam.

FIG. 4. Section of a seminiferous tubule of an underfed ram showing cellular sloughing and accumulation of lipid in the lumen. Interstitial cells are poorly stained. Sudan black. $\times 370$ diam. 


\section{DISCUSSION}

Restriction of food intake resulted in severe impairment of both endocrine and spermatogenic function of the testis. This loss of function was clearly reflected by a reduction both in size and metabolic activity of the testis, and in its blood flow.

The degree of undernutrition imposed in the present experiment must be regarded as severe, since body fat reserves were extremely depleted. Since both protein and energy intake were restricted, it is not clear which of these two

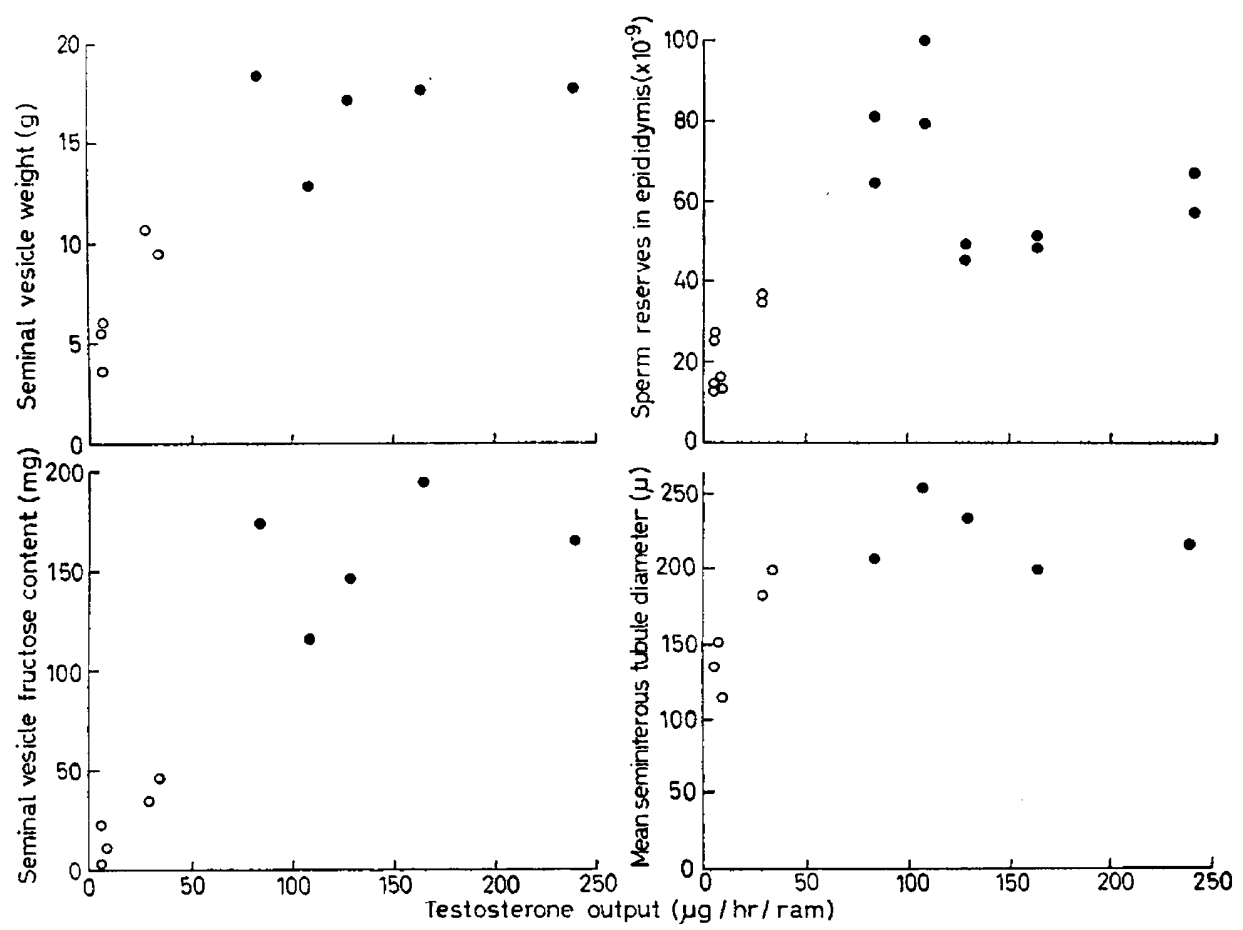

Text-Fig. 4. The relation of testosterone output to seminal vesicle weight and fructose content, mean seminiferous tubule diameter and epididymal sperm reserves in well-fed ( $(\bullet)$ and underfed (O) rams.

factors was limiting, nor can it be decided from the results of the present experiment whether the effects observed were due to a direct action of undernutrition on the testis or whether they were mediated by the anterior pituitary gland.

Many experiments involving castration and testosterone injection indicate that the weight of the accessory glands and the secretion of fructose and citric acid by these glands are dependent on androgen secretion (see Mann \& LutwakMann, 1951), and this relationship has been used to assess the androgen status of underfed animals. Thus seminal vesicles and prostate glands were found to be small in underfed rats and mice (Moore \& Samuels, 1931; Mason, 1933) and contained less fructose and citric acid than in well-fed controls (Lutwak-Mann 
\& Mann, 1951). Fructose and citric acid were lower in the semen of a bull when it was undernourished (Mann \& Walton, 1953), and the appearance of fructose and citric acid in the semen of underfed bull calves was delayed (Davies, Mann \& Rowson, 1957), suggesting that androgen output is reduced by undernutrition. The present results, obtained by direct measurement of the testosterone output of the testis, are in full agreement with these reports.

The observed reduction in the testicular androgen output of underfed rams provides a possible explanation for the observation that libido is decreased in such animals (Mori, 1959), a response resembling that of men during famine (Rubner, 1919; Abel, 1923; de Jongh, 1948; Stolte \& Hoogland, 1948; Davis, 1951; Widdowson, 1951) and experimental undernutrition (Miles, 1919; Keys, Brožek, Henschel, Mickelsen \& Taylor, 1950). However, decreased libido was not noted during marked reduction of body weight in guinea-pigs (Simonowitsch, 1896) and in rams fed a nitrogen-free diet (Warnick, Meacham, Cunha, Loggins, Hentges \& Shirley, 1961), but libido is notoriously difficult to measure and may be affected by many factors other than androgen output.

In the bull, testosterone secretion is closely related to the amount of testosterone in the testis (Lindner, 1961) and the latter is related to the weight of the seminal vesicles, to their content of fructose and citric acid (Lindner \& Mann, 1960) and to the diameter of the seminiferous tubules (Hay, Lindner \& Mann, 1961). A similar relationship between testosterone secretion on the one hand and weight and fructose content of the seminal vesicles and tubular diameter on the other, has now been observed in the ram.

The administration of human chorionic gonadotrophin at least partially reversed the effects of inanition on the size and activity of reproductive organs in male rats and bulls, despite continued underfeeding (Mason \& Wolfe, 1930; Mulinos \& Pomerantz, 1941; Davies, Mann \& Rowson, 1957). These findings lend support to the view that the primary effect of undernutrition is on the rate of release of gonadotrophic hormones from the pituitary gland. However, both Leathem (1959) and Mann \& Rowson (1960) suggested that the responsiveness of androgen target organs was also diminished during inanition. In our experiment, the reduced testosterone production by the testes of the underfed rams in itself may have brought about a further reduction in the activity of the germinal epithelium (Walsh, Cuyler \& McCullagh, 1934; Nelson, 1937; Woods \& Simpson, 1961) and hence in testicular metabolism.

Our estimations of testosterone output were done under different conditions from those previously reported in that the testes of the rams were maintained in their normal relationship to the heart, and blood flow was measured without major surgical interference. Posture is important, for it has been reported that in anaesthetized rams lying on their backs with the testes at about the level of the heart, testicular blood flow was very variable and generally double that of standing rams (Setchell \& Waites, 1964). Thus, the concentration of testosterone in spermatic venous blood collected under anaesthesia from the well-nourished rams was of the same order as that determined in anaesthetized rams lying on their backs by Lindner (1963), but blood flow was considerably lower in the present experiment in which the normal upright posture of the animals was 
maintained. The results obtained with conscious rams suggest that a short period of barbiturate anaesthesia does not appreciably affect the concentration of testosterone in the spermatic venous blood.

In agreement with an earlier finding in the rat (Jackson, 1925), testicular weight was reduced by undernutrition more severely than the weight of the body as a whole. Furthermore, blood flow through unit weight of testis was considerably lower in the underfed rams. The total blood flow through the testis was therefore markedly less in the underfed rams than in the well-fed controls. This difference greatly exceeded the percentage decline in cardiac output observed in man during semi-starvation (Govaert \& Lequîme, 1942; Landes, 1943; Landes \& Arnold, 1947; Keys et al., 1950; Howarth, 1951). Thus, although cardiac output was not determined in the present study, it seems likely that the testis receives a smaller fraction of the cardiac output during undernutrition. Skeletal muscle and skin have also been shown to receive a smaller fraction of the cardiac output during undernutrition (Howarth, 1951), but kidney does not (Dicker, Heller \& Hewer, 1946; Mollison, 1946; McCance, 1951).

The reduction in testicular blood flow in the underfed rams was attended by a reduction in oxygen and glucose uptake. A reduction in oxygen uptake per unit body weight was not a constant finding in man during undernutrition (Beattie \& Herbert, 1947; Howarth, 1951), but when observed, it was proportionately less than the concurrent reduction in cardiac output (Keys et al., 1950). Analogously, arterio-venous differences of oxygen and glucose in the ram testis were the same in well-fed and underfed animals. Hence the observed decrease in oxygen and glucose uptake must be attributed entirely to the changes in blood flow. The decrease in oxygen consumption by the testis contrasts with the increase in oxygen consumption by unit body weight observed in underfed sheep (Graham, 1964).

The oxygen uptake by homogenates and mitochondrial preparations from the testes of underfed rams was generally lower than that of tissue preparations from well-fed rams. Waterlow (1961) observed no change in the respiration of liver homogenates of children during malnutrition, although phosphorylation was decreased. In sheep, metabolic activity of liver mitochondria fell only when the rate of weight loss exceeded $0.15 \mathrm{~kg} /$ day (Koch, 1963). Our sheep were larger than those used by Koch and only one lost more than $0.15 \mathrm{~kg} /$ day during the week before the testis samples were collected. Thus metabolic activity of the testis would seem to be more susceptible to the effects of undernutrition than that of liver. The maximal rates of oxygen uptake observed in vitro $(100 \mu 1$ oxygen $/ \mathrm{mg} \mathrm{N} / \mathrm{hr}$, equivalent to approximately $45 \mu \mathrm{mole} / \mathrm{g}$ fresh weight $/ \mathrm{hr}$ ) were considerably higher than those measured in vivo (about $16 \mu \mathrm{mole} / \mathrm{g} / \mathrm{hr}$ ). It must be borne in mind, however, that the oxygen uptake of homogenates, when substrate and cofactors are not limiting, is not necessarily equivalent to oxygen uptake in vivo but more closely reflects metabolic potential.

The histological appearance of the testes of the underfed rams was similar to that described in underfed rats by Siperstein (1921) and Mason (1933). In view of the importance of glucose in the metabolism of the testis (Annison, Scott \& 
Waites, 1963; Setchell \& Waites, 1964), it is interesting to note that similar lesions were described in hypoglycaemic rats (Mancine, Penkos, Izquierdo \& Heinrich, 1960).

Striking effects on male reproduction have been induced by feeding diets deficient in vitamins A, B or E (Moore \& Samuels, 1931; Mason, 1933; Gunn, Sanders \& Granger, 1942; Lutwak-Mann \& Mann, 1950). There is no reason to believe that our underfed rams were affected by vitamin deficiency, since vitamins A and D were liberally supplied. Vitamin E deficiency is not associated with reproductive abnormalities in sheep (Blaxter \& Brown, 1952), and deficiency of the vitamin $B$ group other than vitamin $B_{12}$ has never been observed in the ruminant because of microbial synthesis of $B$ vitamins in the rumen (Kon \& Porter, 1954). For similar reasons, specific amino-acid deficiencies, which may cause reproductive failure in male laboratory animals (Maun, Cahill \& Davis, 1945, 1946a, b; Adamstone \& Spector, 1950) are unlikely to be important in the ruminant.

Observations at this laboratory (Moule, Braden \& Mattner, to be published) suggest that both androgen output and spermatogenesis of rams were affected more by an inadequate intake of energy than by protein deficiency. However, energy and protein metabolism doubtless interact, as illustrated by the finding of Davis \& Morris (1963) that glucose enhances the in-vitro incorporation of $\left[{ }^{14} \mathrm{C}\right]$ lysine into protein, particularly in the testis.

\section{ACKNOWLEDGMENTS}

We are grateful to Messrs J. K. Voglmayr, B. W. Brown and M. Celenskis for technical assistance.

\section{REFERENGES}

ABEL, A. (1923) Von Hungersnot und Seuchen in Russland. Münch. med. Wschr. 1, 485.

Adamstone, F. B. \& Spector, H. (1950) Tryptophan deficiency in the rat. Arch. Path. Lab. Med. 49, 173.

Amann, R. P. \& Almouist, J. O. (1961) Reproductive capacity of dairy bulls. I. Technique for direct measurement of gonadal and extragonadal sperm reserves. F. Dairy Sci. 44, 1537.

Annison, E. F., Scott, T. W. \& Waites, G. M. H. (1963) The role of glucose and acetate in the oxidative metabolism of the testis and epididymis of the ram. Biochem. $7.88,482$.

Beattie, J. \& Herbert, P. H. (1947) The estimation of the metabolic rate in the starvation state. Brit. F. Nutr. 1, 185.

Blaxter, K. L. \& Brown, F. (1952) Vitamin E in the nutrition of farm animals. Nutr. Abstr. Rev. 22, 1.

Davies, D. V., ManN, T. \& Rowson, L. E. A. (1957) Effect of nutrition on the onset of male sex hormone activity and sperm formation in monozygous bull-calves. Proc. roy. Soc. B, $147,332$.

DAvis, D. R. (1951) Emotional disturbances and emotional reaction. Studies in Undernutrition. Wuppertal 1946-49. Spec. Rep. Ser. med. Res. Coun. Lond. No. 275, p. 147.

DAvis, J. R. \& MORRIs, R. N. (1963) Effect of glucose on incorporation of L-lysine-U-C ${ }^{14}$ into testicular proteins. Amer. 7. Physiol. 205, 833.

DE JoNGH, C. L. (1948) Clinical features of starvation. Malnutrition and Starvation in Western Netherlands, p. 83. General State Printing Office, The Hague.

Dicker, S. E., Heller, H. \& Hewer, T. F. (1946) Renal effects of protein deficient vegetable diets: a functional and histological study. Brit. 7. exp. Path. 27, 158.

Gallagher, G. H. \& Buttery, S. H. (1959) Biochemistry of sheep tissues. Enzyme systems of liver, brain and kidney. Biochem. 7. 72, 575 .

Govaert, P. \& Lequime, J. (1942) Considérations sur la pathogénie des oedemes de famine. Bull. Acad. roy. Méd. Belg. 7, 260.

Graham, N. MCC. (1964) Energetic efficiency of fattening sheep. II. The effects of undernutrition. Aust. F. agric. Res. 15, 113. 
Grandis, V. (1889) La spermatogénése durant l'inanition. Arch. ital. Biol. 12, 215.

Gund, R. M. C., Sanders, R. N. \& Granger, W. (1942) Seminal changes affecting fertility in rams. Studies in Fertility in Sheep. Bull. Coun. sci. industr. Res. Aust. No. 48.

HAy, M. F., Lindner, H. R. \& ManN, T. (1961) Morphology of bull testes and seminal vesicles in relation to testicular androgens. Proc. roy. Soc. B, 154, 433.

Howartir, S. (1951) Cardiac output and the peripheral circulation. Studies in Undernutrition. Wuppertal, 1946-49. Spec. Rep. Ser. med. Res. Coun. Lond. No. 275, p. 238.

HuggetT, A. St. G. \& Nixon, D. A. (1957) Use of glucose oxidase, peroxidase and o-dianisidine in determination of urinary and blood glucose. Lancet, i, 368 .

Jackson, C. M. (1925) The effects of inanition and malnutrition upon growth structure. Blakiston, Philadelphia.

Keys, A., Brožek, J., Henschel, A., Mickelsen, O. \& TAylor, H. L. (1950) The biology of human starvation. University of Minnesota Press, Minneapolis.

KocH, J. H. (1963) The toxic action of phenothiazine and some disturbance of intermediary metabolism in undernourished sheep. Aust. F. agric. Res. 14, 529.

Kon, S. K. \& Porter, J. W. G. (1954) The intestinal synthesis of vitamins in the ruminant. Vitam. Horm. 12, 53.

LANDEs, G. (1943) Kreislaufuntersuchungen bei Eiweissmangelödem. Klin. Wschr. 22, 141.

LANDEs, G. \& ARNold, R. (1947) Weitere Untersuchungen über den Kreislauf bei Ödem Krankheit. Klin. Wschr. 25, 654.

LEATHEM, J. H. (1959) Extragonadal factors in reproduction. Endocrinology of Reproduction. Academic Press, New York.

LiNDNER, H. R. (1961) Androgens and related compounds in the spermatic vein blood of domestic animals. 1. Neutral steroids secreted by the bull testis. F. Endocrin. 23, 139.

Lindner, H. R. (1963) Partition of androgen between the lymph and venous blood of the testis in the ram. F. Endocrin. 25, 483.

Lindner, H. R. \& MANN, T. (1960) Relationship between the content of androgenic steroids in the testes and the secretory activity of the seminal vesicles in the bull. $\mathcal{F}$. Endocrin. 21, 341.

LUTWAK-MANN, C. \& MANN, T. (1950) Restoration of secretory function in male accessory glands by vitamin B deficient rats by means of chorionic gonadotrophin. Nature, Lond. 165, 556.

LutwaK-ManN, C. \& MANN, T. (1951) Effect of malnutrition on the secretory function of male accessory glands of reproduction. Biochem. F. 48, xxvi.

MaCANCE, R. A. (1951) Aspects of renal function and water metabolism. Studies in Undernutrition, Wuppertal 1946-49. Spec. Rep. Ser. med. Res. Coun. Lond. No. 275, p. 175.

McKenzie, H. A. \& Wallace, H. S. (1954) The kjeldahl determination of nitrogen: a critical study of digestion conditions-temperature, catalyst and oxidising agent. Aust. 7. Chem. 7, 55.

Mancine, R. E., Penkos, J. C., Izquierdo, L. A. \& Heinrich, J. J. (1960) Effects of acute hypoglycaemia on rat testis. Proc. Soc. exp. Biol., N.Y. 104, 699.

ManN, T. \& Lutwak-ManN, C. (1951) Secretory function of male accessory organs of reproduction in mammals. Physiol. Rev. 31, 27.

MANN, T. \& Rowson, L. E. A. (1960) Appraisal of androgenic and gonadotrophic activity in male twin calves by chemical analysis of semen and seminal vesicles. 7 . Endocrin. 20, iv.

ManN, T. \& Walton, A. (1953) The effect of underfeeding on the genital function of a bull. J.agric. Sci. 43, 343.

Mason, K. E. (1933) Differences in testis injury and repair after vitamin A deficiency, vitamin E deficiency and inanition. Amer. F. Anat. 52, 153.

Mason, K. E. \& WoLFE, J. M. (1930) The physiological activity of the hypophyses of rats under various experimental conditions. Anat. Rec. 45, 232.

Maun, M. E., GahILL, W. M. \& Davis, R. M. (1945) Morphological studies of rats deprived of essential amino acids. I. Phenylalanine. Arch. Path. Lab. Med. 39, 294.

Maun, M. E., Cahill, W. M. \& Davis, R. M. (1946a) Morphological studies of rats deprived of essential amino acids. II. Leucine. Arch. Path. Lab. Med. 40, 173.

Maun, M. E., Cahill, W. M. \& Davis, R. M. (1946b) Morphological studies of ratsdeprived of essential amino acids. III. Histidine. Arch. Path. Lab. Med. 41, 25.

MiLes, W. R. (1919) The sex expression of men living on a lowered nutritional level. 7. nerv. ment. Dis. 49, 208.

Mollison, P. L. (1946) Observations on cases of starvation at Belsen. Brit. med. J. i, 4.

Montagna, W. (1952) Some cytochemical observations on human testes and epididymides. Ann. N.r. Acad. Sci. 55, 629.

Moore, C. R. \& SAmuels, L. T. (1931) The action of testis hormone in correcting changes induced in the rat prostate and seminal vesicles by vitamin B deficiency or partial inanition. Amer. $\mathcal{J}$. Physiol. 96, 278. 
Mori, A. (1959) Studies on the reproductive failure of ram caused by underfeeding. I. On the effects of underfeeding upon the mating potency of ram, and the effects of normal feeding upon its recovery from impotence. Tohoku 7 . agric. Res. 10, 263.

Moule, G. R. (1963) Postpubertal nutrition and reproduction by the male Aust. vet. 7. 39, 299.

MoustgaARD, J. (1959) Nutrition and reproduction in domestic animals. Reproduction in Domestic Animals. p. 169. Eds. H. H. Gole \& P. T. Cupps. Academic Press, New York.

Mulinos, M. G. \& Pomerantz, L. (1941) The reproductive organs in malnutrition. Effects of chorionic gonadotrophin upon atrophic genitalia of underfed male rats. Endocrinology, 29, 267.

Nelson, W. O. (1937) Some factors involved in the control of the gametogenic and endocrine functions of the testis. Cold Spr. Harb. Symp. quant. Biol. 5, 123.

Ortavant, R. (1952) Recherches sur la spermatogénése des animaux domestiques. Etudes des réserves spermatiques chez le belier. C.R. Soc. Biol., Paris, 146, 1086.

Panaretto, B. A. \& Tile, A. R. (1963) Body composition in vivo. II. The composition of mature goats and its relationship to the antipyrine, tritiated water and $\mathrm{N}$-acetyl-4-aminoantipyrine spaces. Aust. 7. agric. Res. 14, 926.

Porarkov, E. (1913) L'influence du jeûne sur le travail des glandes sexuelles du chien. C.R. Soc. Biol., Paris, 1, 141 .

REID, R. L. (1950) Studies on the carbohydrate metabolism of sheep. 1. The range of blood sugar values under several conditions. Aust. F. agric. Res. 1, 182.

Rubner, M. (1919) Abstract of Report of Professor Rubner made in the Reichgesuntheitrat, December 20th, 1917. Milit. Surg. 44, 237 and 405.

Samuels, L. T. (1950) Relation of nutrition to the anterior pituitary gland. Progr. clin. Endocrin., p. 509.

Setchell, B. P. \& Waites, G. M. H. (1964) Blood flow and the uptake of glucose and oxygen in the testis and epididymis of the ram. 7. Physiol., Lond. 171, 411.

Simonowitsch, J. (1896) Ueber pathologisch-anatomische Veränderungen der Hoden bei vollstandigem und unvollstandigem Hungern der Thiere und Auffutterung nach dem Hungern. Dissertation. St. Petersburg Abstracts in Muhlmann, M. (1899). Russische Literatur über die Pathologie des Hungerns. Zbl. allg. Path. path. Anat. 10, 160 and in Jber. Fortschr. Anat. Entwickl.-gesch. 3, 735 (1897).

SiPERSTEIN, D. M. (1921) The effects of acute and chronic inanition upon the development and structure of the testis in the albino rat. Anat. Rec. 20, 355.

Stolte, J. B. \& Hoogland, P. L. (1948) Patho-physiological aspect of starvation. Malnutrition and Starvation in Western Netherlands. p. 96. General State Printing Office, The Hague.

Threadgold, L. T. (1957) Sudan black and osmic acid as staining agents for testicular interstitial cells. Stain Technol. 32, 267.

Tombs, M. P., Souter, F. \& Maglagan, N. F. (1959) The spectrophotometric determination of protein at $210 \mathrm{~m} \mu$. Biochem. $7 ., 73,167$.

Wattes, G. M. H. \& Serchell, B. P. (1964) Effect of local heating on blood flow and metabolism in the testes of the conscious ram. 7 . Reprod. Fertil. 8, 339.

Walsh, E. L., Cuyler, W. K. \& McCullagh, D. R. (1934) The physiological maintenance of the male sex glands. Amer. 7. Physiol. 107, 508.

Warnick, A. C., Meacham, T. N., Gunha, T. J., Loggins, P. E., Hentges, J. F. \& Shirley, R. L. (1961) Effect of source and levels of nitrogen on semen production and libido in rams. Proc. IVth int. Congr. Anim. Reprod., The Hague, p. 202.

Waterlow, J. G. (1961) Oxidative phosphorylation in the livers of normal and malnourished human infants. Proc. roy. Soc. B, 155, 96.

Werkheiser, W. C. \& Bartley, W. (1957) The study of steady state concentration of internal solutes of mitochondria by rapid centrifugal transfer to a fixation medium. Biochem. F. 66, 79 .

Widdowson, E. M. (1951) The response to unlimited food. Studies in Undernutrition, Wuppertal $1946-49$. Spec. Rep. Ser. med. Res. Coun. Lond., No. 275, p. 313.

Woods, M. G. \& Simpson, M. E. (1961) Pituitary control of the testis of the hypophysectomised rat. Endocrinology, 69, 91 . 